\title{
Las creencias de estudiantes universitarios sobre la escritura en Inglés ${ }^{1}$
}

University students' beliefs about English writing

\author{
Florentina Nicolás Conesa*2 \\ flori.nicolas@cud.upct.es \\ Rosa María Manchón Ruiz** \\ manchon@um.es \\ Julio Roca De Larios** \\ jrl@um.es \\ *Universidad Politécnica de Cartagena, España \\ **Universidad de Murcia, España
}

\section{Resumen:}

Este estudio investiga las creencias de estudiantes sobre varios aspectos de la composición en un contexto de lengua extranjera. Los participantes eran dos grupos de estudiantes universitarios de inglés con diferente cantidad y tipo de experiencias escritora e instrucción. Los datos provenían de un cuestionario completado por los estudiantes y una entrevista con la profesora de escritura. Los resultados indican la existencia de creencias bien fundamentadas sobre el potencial de aprendizaje de la escritura en L2, la dimensión estratégica de la escritura y los procesos de retroalimentación. Otras creencias relacionadas con la dimensión personal de la escritura demostraron ser dependientes del contexto de instrucción. Las implicaciones pedagógicas son discutidas.

\begin{abstract}
:
This study investigates learners' beliefs about various aspects of composition in a foreign language context. The participants were two groups of university students majoring in English who differed in the amount and type of writing experience and instruction. Data came from a questionnaire completed by learners and an interview with the writing teacher. The results are indicative of some well-grounded beliefs about the learning potential of L2 writing, the strategic dimension of writing and the feedback process. Other beliefs related to the personal dimension of writing were found to be context-dependent. The pedagogical implications of these findings are discussed.
\end{abstract}

\section{Acknowledgement:}

The research reported in this paper is part of a progamme of research financed by the Spanish Ministerio de Economía y Competitividad (research grant FF12012-35839) and by Fundación Séneca, the research agency of the Autonomous Government of the region of Murcia, Spain (research Grant 19463/PI/14).

\section{Dirección para correspondencia (correspondence address):}

Florentina Nicolás Conesa. Centro Universitario de la Defensa. Base Aérea de San Javier. C/ Coronel López Peña, s/n. 30720 Santiago de la Ribera, Murcia (España). 


\section{Palabras clave:}

Creencias sobre la escritura; aprendizaje de lengua extranjeras; contexto de aprendizaje.

\section{Keywords:}

Writing beliefs; foreign language learning; learning context.

\section{Résumé:}

Cette étude examine les croyances des étudiants sur divers aspects de la composition dans le contexte de l'apprentissage d'une langue étrangère. Les participants se composaient de deux groupes d'étudiants universitaires d'anglais avec différents nombre et types d'expérience et d'instruction dans le domaine de l'écriture. Les données procèdent d'un questionnaire rempli par les élèves et d'une interview à leur professeur d'écriture. Les résultats indiquent l'existence de croyances fondées sur le potentiel de l'apprentissage de l'écriture en L2, sur la dimension stratégique des processus d'écriture et de rétroaction. D'autres certitudes liées à la dimension de l'écriture personnelle se sont montrées dépendantes du contexte de l'instruction. Les implications pédagogiques sont débattues.

\section{Mots-clés:}

Croyances sur l'écriture; apprentissage d'une langue étrangère; contexte d'apprentissage.

Fecha de recepción: 3-11-2014

Fecha de aceptación: 26-2-2015

\section{Introduction}

The study of beliefs in language learning is a central area of inquiry in second language acquisition (SLA) research given their influence on students' achievement (e.g. Gan, 2004). Students' beliefs are shaped as a result of learning experiences and they are therefore contextual, socially constructed and dynamic (Barcelos, 2003). Most research on L2 students' beliefs has focused on language learning (cf. Mori, 1999a; 1999b) but few studies have delved into learners' beliefs on language use (i.e. speaking, listening, reading and writing) and their possible pedagogical implications. Our empirical study attempts to contribute to fill this gap in research by focusing on the study of 32 Spanish university students' beliefs systems for composing in L2 bearing in mind the influence of two different instructional contexts. In what follows, we review why beliefs are important for language learning and the main approaches that have been adopted for their investigation. We will then concentrate on beliefs in the field of writing, which is the area of interest in the current investigation.

Scholars of educational psychology agree on the importance of beliefs for language learning (cf. Hofer \& Pintrich, 2002) on account of 
the crucial role that students' conceptions are thought to play in the engagement in language learning actions. The body of research on the beliefs that L2 learners hold and on the social factors and educational experiences that influence their shaping has been informed by various theoretical and methodological frameworks, which have been summarized under three main comprehensive approaches by Barcelos (2003, 2006) in what can be considered to be the most exhaustive classification of language learning beliefs. These approaches are the Normative, the Metacognitive, and the Contextual. The three approaches share the assumption that beliefs influence students' use of language learning strategies or their behaviour in language learning (Horwitz, 1988; Wenden, 1987), but they differ with respect to their definitions of beliefs that guide research.

The studies included within the Normative Approach define beliefs as preconceived notions (Horwitz, 1988) that can be inferred from a predetermined set of statements and be examined out of context. Within the Metacognitive Approach, beliefs are viewed as a subset of metacognitive knowledge, defined by Wenden as "the stable, statable, although sometimes incorrect knowledge that learners have acquired about language, learning and the language learning process" (Wenden, 1987: 163). Flavell (1979) distinguished three different types of beliefs within metacognitive knowledge: person, task and strategic knowledge. Person knowledge involves what students think about themselves as learners, their self-efficacy beliefs, and their ability to use resources to sustain their effort in their learning process. Students' maintenance of effort can be equated with self-regulation, which is defined as learners' monitoring of their learning process at a metacognitive, motivational and behavioural level during their learning process that can result in achievement (Zimmerman, 2001). Task knowledge includes what learners believe about the characteristics of the learning task and its purpose, which is different from domain knowledge (what the learner knows about a given subject matter). Lastly, strategic knowledge applies to what students think about what strategies are, why they are useful, and how and when they should be used to achieve various cognitive goals. In this approach, students are assumed to reflect on their learning process and to be able to describe their beliefs related to their target language, their L2 proficiency, the results of their learning approach, their role in language learning or their beliefs about the best way to learn languages (Wenden, 1987). Finally, 
the last group of studies on learners' beliefs is represented by the Contextual Approach. The main aim of this approach is to better understand the function of beliefs in specific learning environments rather than to make generalizations of beliefs about SLA. Context here is regarded as "socially constituted (...) in which each additional move within the interaction modifies the existing context while creating a new arena for subsequent interaction" (Goodwin \& Duranti, 1992: 5-6).

All the studies on beliefs within the three approaches have focused on the learning dimension of SLA processes. Curiously enough, the dimension of language use, and more specifically, the area of beliefs about writing, has not been so intensively investigated with some exceptions (e.g. Manchón \& Roca de Larios, 2011; Sengupta, 2000). Within the area of writing, some researchers have examined the effects of explicit writing instruction on the shaping of beliefs. For instance, Sengupta (2000) carried out an exploratory study about the effects of instruction on revision strategies for composing. After one year of tuition, there was a change in the students' cognitive models because they moved from a uni-dimensional model of writing (in which accuracy was the main factor) to a multidimensional model (which included awareness of other factors such as the reader of their text). Along the same lines, Manchón, (2009) showed how a group of students who took a writing course during an academic year changed their beliefs about the task (more multidimensional mental model of writing) about themselves (increase in self-efficacy beliefs) and about the role of the teacher (from correcting texts to giving feedback).

Given the importance of students' metacognitive knowledge for learning achievement and the positive effects of writing instruction on the development of beliefs, we decided to delve into the idiosyncratic shaping of university students' beliefs systems bearing in mind their literacy experiences. Differing from previous studies in which writing instruction and their immediate effects on beliefs were restricted to a specific group of learners in a writing course at the moment of data collection (e.g. Manchón \& Roca de Larios, 2011), our investigation focused on the possible long-term effects of instruction drawing on Mori's contention (1999a: 409) that "beliefs cannot be easily or quickly modified because they are formed over a long period". In addition, the instructional context in our study is also worth highlighting since both learning-to-write and writing-to-learn approaches (see Manchón, 2011) were fostered. Those 
approaches describe how L2 users learn to convey their intended meaning in writing, on the one hand, and, on the other, how the involvement in L2 writing tasks can help students to learn about content knowledge or language. With some exceptions (e.g. Manchón \& Roca de Larios, 2011), most L2 writing studies have mainly focused on learning-to-write contexts and the writing-to-learn dimension has normally been theorized and explored within second language acquisition (SLA) research. Accordingly, in our study we also expect to contribute to the investigation of beliefs within a context that fosters the enhancement of L2 language through writing while it also allows the development of writing abilities. In other words, our participants' learning context facilitated the exploration of FL writing and SLA interfaces.

The aim of this exploratory study was to shed light on the shaping of university students' beliefs system about various dimensions of L2 composition across time on account of their literacy experiences (Gan, 2004). Since we were also interested in the possible long-term effects of changes in learners' writing beliefs, we compared the beliefs of two independent groups of participants who were at two different points of writing instruction in an English for Academic Purposes (EAP) course, that is, during and after taking it. The specific research questions (RQ) were formulated as follows:

1. Are there any differences in the beliefs about writing between students at different levels of instruction and writing experience?

2. Which common beliefs do students at different levels of instruction and writing experience hold about L2 writing?

The study was cross-sectional in nature. We drew on the contextual approach to the investigation of beliefs due to our exploration of the dynamic nature of language use beliefs as they develop and shape in context, although we also made use of the metacognitive approach from a conceptual viewpoint. In this respect, learners' beliefs were operationalised as metacognitive knowledge, as we further explain in the next section. 


\section{Method}

\subsection{Participants and Context}

Our participants were a group of fourth and fifth year learners of a fiveyear English degree at a Spanish university. By the time the students reached the fourth and fifth year, they had already taken three compulsory annual language courses which were designed to take them from preintermediate to proficiency language level and were devoted to grammar as well as to speaking, listening, reading and writing in L2.

Although students had to compose some occasional essays for those courses, the most important contact with academic writing took place in the fourth year, when learners needed to write assignments in English for their subject content courses and they also took a compulsory EAP course that lasted for nine months and for which they had to write academic texts on weekly basis. The aim of the writing course was to help students develop their reading and writing skills beyond linguistic accuracy. Students wrote three compulsory major assignments that were rewritten three times after having received personal feedback on them from peers and from the writing teacher. Regarding the instructor of the EAP course, she is a native speaker of English with more than twenty-five years of experience in EFL teaching in Spain. She is also a researcher with more than ten years of active involvement in different research projects on second language writing. When the data were gathered for the present study she had been teaching the EAP course for five years.

Thirty-two foreign language university students participated in this study. Nineteen of them were taking $4^{\text {th }}$ year courses during a five-year English degree at a Spanish university while thirteen students were enrolled in the fifth year of the same degree. The participants were native speakers of Spanish and the majority of them were women (15 in the fourth year and 10 in the fifth year). Their mean age was 21 for the fourth year and 22 for the fifth year group.

The two groups of participants differed mainly with respect to their writing experience and formal academic instruction in composition due to the fact that the fifth year learners had already taken the EAP course the previous academic year. The present research is a followed-up study of the fifth year learners. One year before collecting data for the present study, our research team had examined Manchón, (2009) five months 
apart the shaping of the fifth year learners' beliefs while taking the EAP course. The results indicated significant changes across time regarding (i) an increase in self-efficacy beliefs for writing academic texts; (ii) learners' beliefs about the role of the teacher (from focusing on linguistic correction to content and rhetoric) and (iii) students' move towards a more positive stance towards the usefulness of giving and receiving both peer and teacher feedback. At the time of data collection for this study, the fifth year learners were only taking subject content courses for which they needed to write academic assignments made up of one final draft submission without receiving feedback, while the fourth year group was taking the EAP course in combination with other subject content courses for which they also wrote occasional assignments.

\subsection{Instruments and Procedures}

Data for the study came from two main sources: quantitative data obtained by means of a written questionnaire on the dependent variable of the study (beliefs about writing) and qualitative data elicited through an interview with the writing teacher. The questionnaire was administered four months after having started the academic year so that learners had already had time to get acquainted with their courses. The interview with the writing teacher was conducted the last month of the academic year and it was intended as a secondary source of information on the teacher's views of the aims and organisation of the course that could help us to understand some of the learners' responses in the questionnaire. We opted for the use of a questionnaire and a semi-structured interview with the writing teacher so as to gather introspective information about students' perceptions and interpretations of their learning experiences $\left(\mathrm{O}^{\prime}\right.$ Malley \& Chamot, 1990).

Given that most of the studies on beliefs has focused on language learning (Barcelos, 2003; Mori, 1999a, 1999b) or on epistemological beliefs, that is, the nature of knowledge and learning (see Hofer \& Pintrich, 2002 for a review), we needed to design our own questionnaire. The Beliefs about Writing Questionnaire (BWQ) was totally developed by our research team due to the fact that no questionnaires on beliefs about writing could be found in the literature. Drawing on previous empirical research on beliefs (cf. Mori, 1999a, 1999b; Schommer, 1990), we developed a multi-dimensional questionnaire that tapped several theo- 
retical and pedagogical dimensions of L2 writing. We focused on five dimensions of beliefs about writing. Three of them corresponded to the three components of metacognitive knowledge (person, task and strategy) to which two further dimensions were added on account of their possible pedagogical interest: beliefs about the writing teacher, on the one hand, and about the nature, uses and forms of feedback, on the other. Care was also taken to select categories that could be context sensitive so as to increase the validity of the questionnaire (Petric \& Czarl, 2003). The BWQ was made up of 21 items (cronbach alpha=.74) and the participants' agreement or disagreement with each item of the questionnaire was rated by a 5 point Likert-scale in which 5 represented strong agreement and 1 strong disagreement.

\subsection{Data Analysis}

The participants' responses to the BWQ were analyzed quantitatively. Due to the small sample size of the study, non parametric statistics was used. A Mann-Whitney $U$ test was conducted to compare the responses of the fourth and the fifth year group students. As for the interview with the writing teacher, we carried out a content analysis.

\section{Results}

In this section, we shall report the main findings obtained with respect to each of the research questions guiding the study.

\section{RQ1: Are there any differences in the beliefs about writing between students at different levels of instruction in the degree of English Philology?}

As can be seen in Table 1, statistically significant differences were found between both groups of learners with respect to their beliefs about the person dimension, including (i) self-efficacy beliefs (Items 1 and 2); and (ii) human factors and their role in language learning (Items 3, 4 and 5).

Regarding self-efficacy beliefs, two main aspects were shown to be statistically significant: the students' confidence in their writing ability (Item 1 BWQ: $p=.044$ ) and their reliance on being able to improve their 
writing skills (Item 2 BWQ: $p=.008$ ). Learners in the fourth year were the most confident in their writing abilities since they believed that they would learn how to write complex academic texts during the academic course. Likewise, learners in the fourth year group were more self-assured than the fifth year students about their capacity of improving their writing skills.

Other significant differences referred to learners' beliefs about human factors and their role in language learning. The differences comprised students' beliefs on previous writing experiences (Item 3 BWQ: $p=.006$ ), on their self-regulation beliefs (Item 4 BWQ: $p=.006$ ) and on their beliefs about their instructors (Item 5 BWQ: $p=0.31$ ).

As for their previous experiences, the fourth year students tended to believe that they had not learnt enough in past courses to complete their current writing assignments successfully, while the fifth year participants claimed to have received satisfactory instruction. Regarding self-regulation beliefs, the fourth year participants stated that they were responsible for their own learning and, therefore, they reported to a greater extent than the fifth year group needing to work hard and to make efforts to compose their writing assignments. With respect to the role of their instructors, the fourth year students tended to believe that their instructors were concerned about how they wrote (linguistic accuracy) rather than the content of their texts, while the fifth year group considered that their teachers were rather focused on the content of their writing.

\section{Table 1. Mann-Whitney U Test. Statistically significant differences in BWQ.}

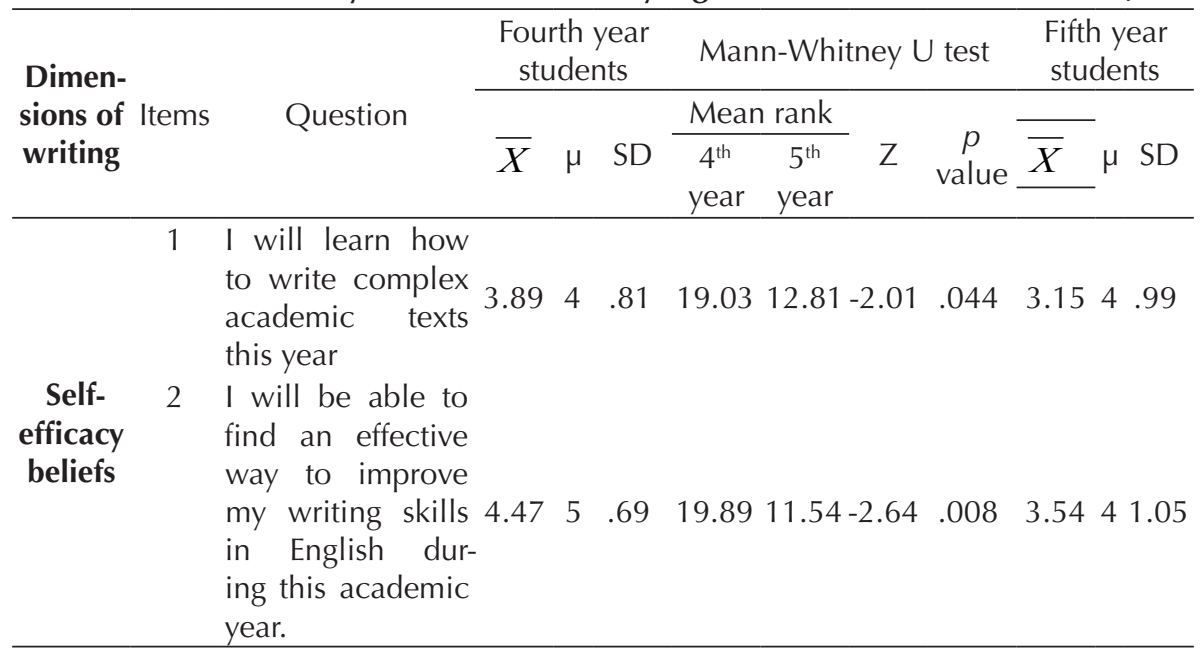




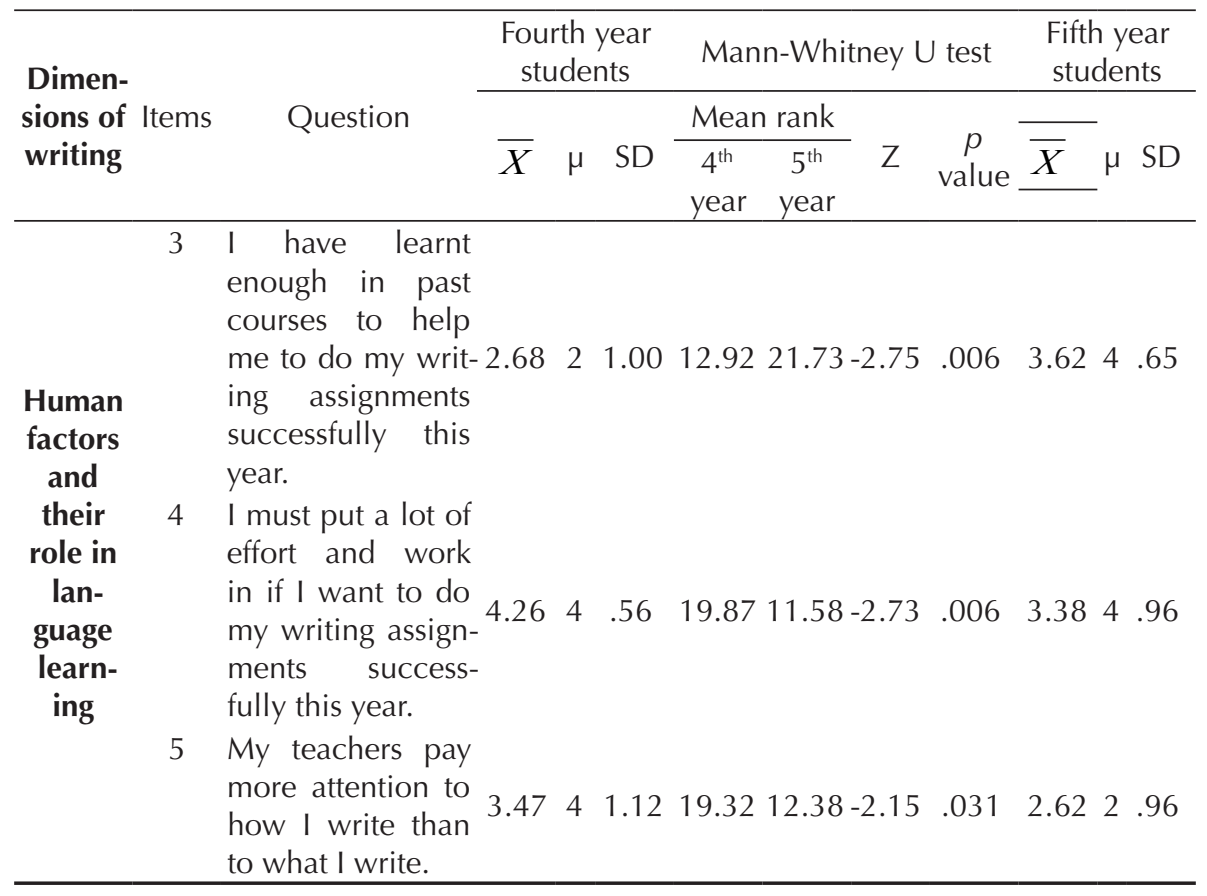

Apart from these differences, there were also common beliefs about writing that were held by both groups of foreign language learners. We were interested in exploring the similarities between the two groups of foreign language learners' beliefs so as to identify the existence of common patterns regardless of the influence of the writing instruction in the EAP course.

\section{RQ2: Which common beliefs do students at different levels of instruction in the degree of English Philology hold about L2 writing?}

The commonalities in learners' beliefs were grouped into three main dimensions of writing: the task, the strategy and the feedback dimensions (see Table 2). 
Table 2. Descriptive statistics of fourth and fifth year learners' beliefs about the task dimension, the strategic and feedback dimensions of writing.

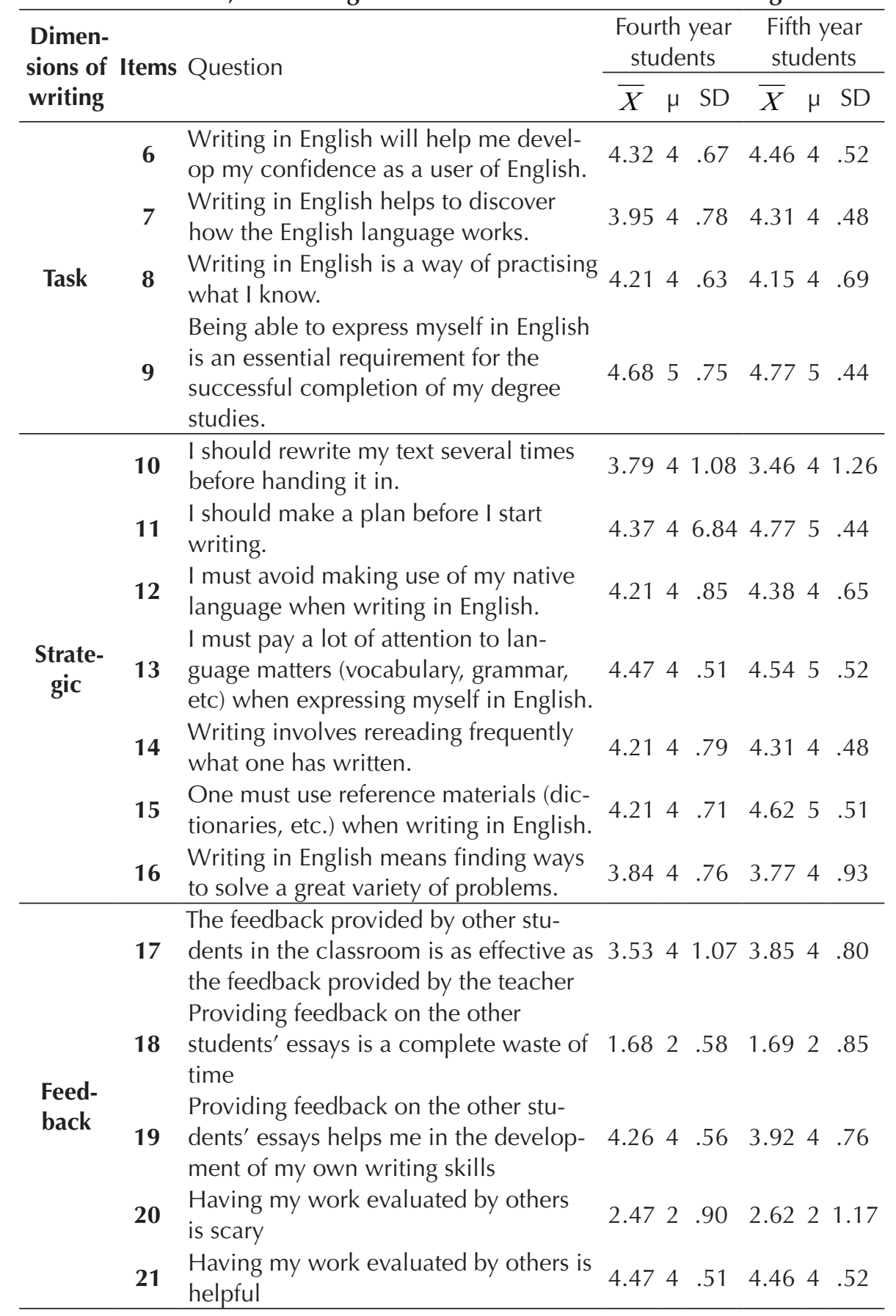


The task dimension included two subcategories of learners' beliefs about the purpose of writing and the nature of writing. As shown in table 2, both groups stated that writing in English helped them to develop their confidence as learners of a foreign language (Item 6). In addition, they also recognised the language learning potential of L2 composing that helped them both to acquire new linguistic knowledge (Item 7) and to put into practice their knowledge of the L2 (Item 8). Accordingly, for both groups of students the activity of writing in English was regarded as an essential requirement for their degree studies that helped them to satisfy their language learning needs (Item 9).

The strategic dimension was made up of students' beliefs about the implementation of writing strategies. Students in both years tended to consider the activity of writing as a problem-solving task (Item 16) for which they needed to make a plan before starting to write (Item 11), reread several times what they wrote (Item 14), and rewrite their texts several times before handing them in (Item 10).

Once they began their process of composition, fourth and fifth year learners stated that the use of the L1 should be avoided (Item 12) because they should think in the language in which they write, English in this case. Their L2 concerns also made them try to find the most appropriate linguistic expressions (vocabulary and grammar) (Item 13) and use reference materials when necessary (Item 15).

Finally, the feedback dimension gathered information on the students' stance towards giving and receiving feedback. Learners in both groups expressed the belief that both providing feedback and processing the feedback provided to them by peers or the teacher was useful (Item 18) as well as a way of helping them to develop their own writing skills (Item 19). The writing teacher also held these beliefs about the beneficial effects of providing feedback to others as shown in this extract of the interview:

[1] The reading of somebody else's text and looking for problems that can be solved in that text is... demands a lot of critical abilities: focusing, analysing... it's a very high level and that, and it can be applied to their own text; that level of analysis that they develop by doing that can then be applied to their own texts. So it sharpens their own abilities to analyse texts (...) I think it's (peer feedback) helpful because it weans dependence from the teacher. 
Both groups also reported that having their work evaluated by others was helpful (Item 21) and, therefore peer feedback did not create feelings of uneasiness (Item 20). In addition, they also equated the feedback provided by other students as effective as the teacher's correction (Item 17) as a result of the cooperative classrooms that the writing teacher helped to create in her lessons through her talk and teaching practices that included the technique of peer feedback.

\section{Discussion}

The aim of this study was to investigate two groups of EFL students' beliefs systems in writing. The results offer empirical evidence of the malleability of beliefs (cf. Schommer, 1990) as a result of experience and learning (Mori, 1999a: 410) and of contextual factors (Barcelos, 2003). While some students' beliefs seemed to be well-grounded provided that certain instruction and writing practice had previously been fostered, other beliefs related to the person dimension of writing and to the role of instructors were highly dependent on the current writing opportunities offered in each course, as we shall explain next.

Regarding commonalities in learners' beliefs, participants in both groups held general and common conceptions of learning and the writing task, of the strategic dimension (writing as a problem solving task and avoidance of the L1), of the task dimension (L2 learning potential of writing), and of the feedback dimension of writing (the usefulness of peer and teacher feedback). These similarities seem to be illustrative of beliefs commonly held by language students in a foreign language context with restricted language learning and practice opportunities outside the L2 classroom.

Both groups referred to the strategic dimension of writing and defined composing as a problem-solving, recursive process involving macrofeatures such as planning, reading and writing, as well as attention to micro-linguistic aspects of composing. These findings are in line with previous studies about the effects of instruction on the shaping of multidimensional beliefs about the writing task (Sengupta, 2000). Furthermore, as was the case with the fifth year learners, the results indicate that these conceptions of writing can be maintained across time provided that learners have realized through practice and instruction of some in- 
herent elements related to the ill-defined nature of the writing task and its dynamic problem representation and reformulation. Closely linked to the problem-solving dimension of writing are beliefs about the learning potential of composing via intensive writing practice. As perceived by both groups of participants, the writing task helped them both to acquire new linguistic knowledge and to put into practice their L2 language as a result of producing their texts, giving feedback to their peers as well as processing the feedback received about their production, may it come from peers or the writing teacher. These findings highlight the role that written output may play in promoting language development (see Manchón \& Roca de Larios, 2007, for a review) (cf. Manchón, 2011; Williams, 2012), and it may thus be regarded as indicative of the interface between SLA and L2 writing research (Ortega, 2012; Ortega \& Carson, 2010) in a foreign language environment.

With respect to differences in learners' beliefs, they were related to writer and to instructors and they seemed to be more dependent on the learning context. The shaping of beliefs about the person dimension of writing (self-efficacy and self-regulation) was found to vary in relation to the students' specific learning situation (Barcelos, 2003; Hosenfeld, 2003). These results provide insights into the activation of a situational interest in writing, which appeared to be triggered and vanished in immediate response to the stimuli of the learning environment and might not last long (Hidi \& Renninger, 2006) in spite of learners' realisation of the beneficial effects of writing for (i) the successful completion of their studies; (ii) the potential to practise and develop their L2 knowledge; and (iii) the development of their confidence as L2 users. Accordingly, during the EAP course students developed a situational interest in writing, which was context-dependent, rather than a personal interest that could lead to continuous involvement in learning (Schiefele, Krapp, \& Winteler, 1992). This absence of personal interest could explain why the fifth year learners showed having (i) lower self-regulation for writing in subject content courses in comparison with the fourth year students who wrote for the EAP course; (ii) lower self-efficacy beliefs about the possibilities for improving their writing skills over their academic year in which they did not have a specific course of writing tailored to their needs.

It should be reminded that the fifth year learners' increased their selfefficacy beliefs during the previous academic year in which they took the writing course. In other words, the fifth year students were not self- 
regulated learners who could struggle for writing improvement in the assignments of their subject content courses even though they reported having learnt enough about writing in the past so as to compose successfully their assignments in their current academic year. All participants seemed to be dependent on the feedback provided by the writing teacher to monitor their writing process and feel confident about their writing improvement.

Self-efficacy beliefs and self-regulation are interrelated since conceptions of personal abilities to perform a given task are needed for students' monitoring of their own learning (Bandura, 2001; Pajares, 2003). More confident students (the fourth year group) about their chances to improve their writing skills also appeared to be more self-regulated and better prepared to get involved in motivated behaviour for learning (Dörnyei, 2005; Gardner, 2006) by means of controlling their effort and work when writing. Fifth year students' low self-regulation for writing in absence of a specific writing course offers support to Sasaki's (2009) contention about the purposeless nature of foreign language writing, a context in which learners may not need to pursue further improvement in L2 writing once they have finished their formal instruction in writing courses.

Our participants' interpretation of contextual constraints for writing seemed to be essential in the activation of their self-efficacy and selfregulation beliefs. The fifth year learners perceived their current learning environment as less responsive to develop or maintain their writing skills in comparison with the fourth year group due to the absence of rewriting procedures in their subject content courses. By the same token, the fourth year students' beliefs about their composing skills and about their needed effort to write and improve their writing were conditioned by the combination of both a responsive environment (Ford, 1992) for writing development in which they were immersed and the confidence in their skills. Along the same lines, students in both groups also had different opinions about their instructors' writing concerns as a result not only of the courses they were currently taking, as indicated in previous research (cf. Ezer \& Sivan, 2005; Leki, 1995), but also of the courses that they considered to have a greater impact on the development of their writing skills at the time of data collection. In this respect, the fourth year group stated that their instructors focused more on the way they wrote their compositions than on the content of their essays because they were 
thinking of their EAP teacher rather than other subject content instructors for whom they also needed to write assignments.

As a whole, learners' beliefs must be understood within a specific learning situation in which the presence of high writing demands determines students' L2 writing conceptions and behaviour. In view of these results, a pedagogical implication can also be drawn in relation to instructors' practices. It could be argued that the characteristics of writing tasks in subject content courses that require one final submission draft may not help learners to maintain the self-efficacy beliefs and self-regulation that have been developed in other writing courses. It could also be suggested that the development of L2 learners' language and writing skills might be negatively affected across time if students are only enrolled in subject content courses that do not challenge them to put into practice their content knowledge through writing. These are important aspects to consider in a foreign language environment that could be taken into account not only in EAP courses, but also in subject content ones given (i) the limiting L2 learning and writing opportunities available for foreign language learners outside formal teaching contexts; (ii) and the suggestive students' beliefs about the learning potential of L2 writing. Although our students' beliefs about the potential of writing were related to L2 language, writing tasks could also be beneficial to help EFL students to learn about content knowledge in subject content courses by promoting better understanding of the concepts, and reflecting on them through analytical inquiry (e.g. Newell, 2005; Newell, Koukis, \& Boster, 2006). In other words, subject content courses in foreign language settings could provide learners with opportunities to enhance their L2 knowledge and writing abilities through multiple drafts that foster the constant confrontation of problems to be solved about real communicative purposes. This approach to learners' writing tasks could help to overcome some of the problems attributed to FL settings that are considered less purposeful and needs driven than SL contexts (Ortega, 2009).

We suggest that a change in teaching practices related to writing at university could be beneficial to the whole educational system and could lead in the long run to the creation of an L2 writing tradition in schools and high-schools that up to now is missing in countries like Spain. We propose that if university students in Spain, who may become prospective English teachers in schools and high-schools, get used to both learning-to-write and writing in order to learn (the L2 language or content in 
subject content courses) (see Manchón, 2011) on a regular basis, they might understand the potential of writing for language and content learning, and foster those same writing practices in their future lessons when they become teachers.

\section{Conclusion}

This study confirms the results of previous research about the influence of educational experiences on the shaping of L2 learners' beliefs (Chamot, 2005; Gan, 2004), the development of a multidimensional model of writing in which concerns for lower and higher level of concerns can coexist (Sengupta, 2000), and the shaping of students' beliefs about the L2 learning potential of writing practice and feedback (cf. Swain, 1995; Manchón \& Roca de Larios, 2011). It also adds to previous research that well-grounded beliefs can be maintained after a period of writing instruction (as in the case of the fifth year group), while beliefs about the person (about student-writers or instructors) seem to be more dependent on the current learning situation. The learning context must offer a supportive environment for writing engagement so as to ensure the activation and control of learners' self-efficacy beliefs and self-regulation for writing.

Our study has also some methodological limitations. The sample size was small and the use of questionnaires limited learners' responses to a set of beliefs offering a partial view of their beliefs systems in context. Future studies could further investigate the shaping of learners' beliefs during longer periods of time using interviews. Research on writer-students' beliefs could also be enriched with the exploration of other writerinternal factors such as the shaping and monitoring of students' goals for composing in EFL contexts, given that learners' goals can provide insights into their motivation, self-efficacy beliefs and self-regulation for writing. Although limited in scope, the present study could be considered a worthwhile attempt to help to delve into the investigation of the shaping of writers' beliefs that are shown to be mediated by writing experiences and the different opportunities offered for learning-to-write and writing-to-learn in a foreign language context. 


\section{References}

Bandura, A. (2001). "Social cognitive theory: An agentic perspective", in Annual Review of Psychology, 52, 1-26

Barcelos, A.M.F. (2003). "Researching beliefs about SLA: A critical review", in P. Kalaja \& A.M.F. Barcelos (eds.), Beliefs about SLA. New Research Approaches. New York: Springer, 7-33.

Chamot, A.U. (2005). "The cognitive academic language learning approach (CALLA): An update", in P.A. Richard-Amato \& M.A. Snow (eds.), Academic Success for English Language Learners: Strategies for K-12 Subject Content Teachers. New York: Longman, 87-101.

Dörnyei, Z. (2005). The Psychology of the Language Learner: Individual Differences in Second Language Acquisition. Mahwah, NJ: Lawrence Erlbaum.

Ezer, H., \& Sivan, T. (2005). "Good academic writing in Hebrew: The perceptions of preservice teachers and their instructors", in Assessing Writing, 10, 2: 117-133.

Flavell, J. H. (1979). "Metacognition and cognitive monitoring. A new area of cognitivedevelopmental inquiry", in American Psychologist, 34, 10: 906-911.

Ford, M. (1992). Motivating Humans: Goals, Emotions, and Personal Agency Beliefs. Newbury Park: Sage.

Gan, Z. (2004). "Attitudes and strategies as predictors of self-directed language learning in an EFL context", in International Journal of Applied Linguistics, 14, 3: 390-411.

Gardner, R. (2006). "The socio-educational model of second language acquisition: a research paradigm", in EUROSLA Yearbook, 6, 237-260.

Goodwin, C., \& Duranti, A. (1992). "Rethinking context: An introduction", in A. Duranti, \& C. Goodwin (eds.), Rethinking Context. Language as an Interactive Phenomenon. Cambridge: Cambridge University Press, 1-42.

Hidi, S. \& Renninger, K. A. (2006). "The four-phase model of interest development", in Educational Psychologist, 41, 2: 111-127

Hofer, B.K., Pintrich, P. R. (eds.), (2002). Personal Epistemology. The Psychology of Beliefs about Knowledge and Knowing. Mahwah, NJ: Erlbaum.

Horwitz, E.K. (1988). "The beliefs about language learning of beginning foreign language students", in The Modern Language Journal, 72, 3: 283-294.

Hosenfeld, C. (2003) "Evidence of emergent beliefs of a second language learner". In P. Kalaja \& A.M.F. Barcelos (eds.), Beliefs About SLA: New Research Approaches. Dordrecht: Kluwer, pp. 37-54.

Leki, I. (1995). "Coping strategies of ESL students in writing tasks across the curriculum", in TESOL Quarterly, 29, 2: 235-260.

Manchón, R.M. (2009). "Individual differences in foreign language learning: The dynamics of beliefs about L2 writing" in Revista Española de Lingüística Aplicada, 22, 245268.

Manchón, R.M. (Ed.), (2011). Learning to Write and Writing to Learn in an Additional Language. Philadelphia, PA: John Benjamins.

Manchón, R.M., Murphy, L., \& Roca de Larios, J. (2007). "Investigating beliefs about writing and composing strategy implementation. The effect of instruction and practice", 
Las creencias de estudiantes universitarios sobre la escritura en Inglés Florentina Nicolás Conesa, Rosa María Manchón Ruiz y Julio Roca De larios

in M. Conrick \& M. Howard (eds.), From Applied Linguistics to Linguistics Applied: Issues, Practices, Trends. London: BAAL, 76-90.

Manchón, R.M. \& Roca de Larios, J. (2007). “On the temporal nature of planning in L1 and L2 composing: A study of foreign language writers", in Language Learning, 57, 4: 549-593.

Manchón, R.M.,\& Roca de Larios, J. (2011). "Writing to learn in FL contexts: Exploring learners' perceptions of the language learning potential of L2 writing", in R.M. Manchón (ed.), Learning-to-Write and Writing-to-Learn in an Additional Language. Amsterdam and Philadelphia: John Benjamins, 181-207.

Mori, Y. (1999a). "Beliefs about language learning and their relationship to the ability to integrate information from word parts and contexts in interpreting novel Kanji words", in The Modern Language Journal, 99, 534-547.

Mori, Y. (1999b). "Epistemological beliefs and language learning beliefs: What do language learners believe about their learning?", in Language Learning, 49, 3: 377-415.

Newell, G.E. (2005). "Writing to learn: How alternative theories of school writing account for student performance", in C.A.MacArthur, S. Graham, \& J. Fitzgerald, (eds.), Handbook of Writing Research. New York: Guilford Publications, 235-247.

Newell, G.E., Koukis, S., \& Boster, S. (2006). "Best practices in writing to learn", in C.A. MacArthur, S.Graham, \& J. Fitzgerald, (eds.), Best Practices in Writing Instruction. New York: Guilford Publications.

O'Malley, J.M., \& Chamot, A.U. (1990). Learning Strategies in Second Language Acquisition. Cambridge: Cambridge University Press.

Ortega, L. (2009). "Studying writing across EFL contexts: Looking back and moving forward", in R.M. Manchón (ed.), Writing in Foreign Language Contexts: Learning, Teaching, and Research. UK: Clevedon: Multilingual Matters, 232-255.

Ortega, L. (2012). "Epilogue: Exploring L2 writing-SLA interfaces" in Journal of Second Language Writing, 21,4: 404-415.

Ortega, L., \& Carson, J. G. (2010). "Multicompetence, social context, and L2 writing research praxis", in T. Silva \& P. Matsuda (eds.), Practicing Theory in Second Language Writing. West Lafayette: Parlor Press, 48-71.

Pajares, F. (2003). "Self-efficacy beliefs, motivation, and achievement in writing: A review of the literature", in Reading \& Writing Quarterly, 19, 2: 139-158.

Petric, B., Czarl, B. (2003). "Validating a writing strategy questionnaire" in System, 31, 2: $187-215$.

Sasaki, M. (2009). "Changes in EFL students' writing over 3.5 years: A socio-cognitive account", in R. M. Manchón (ed.), Learning, Teaching, and Researching Writing in Foreign Language Contexts. Clevedon, England: Multilingual Matters, 49-76.

Schiefele, U., Krapp, A., \& Winteler, A. (1992). "Interest as a predictor of academic achievement: A meta-analysis of research", in K. A. Renninger, S. Hidi, \& A. Krapp (eds.), The Role of Interest in Learning and Development. Hillsdale, NJ: Erlbaum, 183212.

Schommer, M. (1990). "Effects of beliefs about the nature of knowledge in comprehension" in Journal of Educational Psychology, 82, 3: 498-504.

Sengupta, S. (2000). "An investigation into the effects of revision strategy instruction on 
L2 secondary school learners", in System, 28, 1: 97-113.

Swain, M. (1995). "Three functions of output in second language learning" in G. Cook \& B.Seidlhofer (eds.), Principles and Practice in the Study of Language. Oxford: Oxford University Press, 125-144.

Wenden, A. L. (1987). "Incorporating learner training in the classroom", in A. Wenden, \& J. Rubin (eds.), Learner Strategies in Language Learning. Englewood Cliffs, NJ: Prentice Hall, 159-168.

Williams, J. (2012). "The potential role(s) of writing in second language development", in Journal of Second Language Writing, 21, 321-331.

Zimmerman, B.J. (2001). "Theories of self-regulated learning and academic achievement: An overview and analysis" in B. J. Zimmerman \& D. H. Schunk (eds.), Self-regulated Learning and Academic Achievement: Theoretical Perspectives (2nd ed). Mahwah, NJ: Erlbaum, 1-37. 